\title{
STUDIES OF ISCHAEMIC AND POST-ISCHAEMIC PARAESTHESIAE IN NORMAL SUBJECTS AND IN SCIATICA
}

\author{
BY \\ JOHN MARSHALL \\ From the Military Hospital, Wheatley, and Department of Neurology, United Oxford Hospitals
}

The occurrence of paraesthesiae during occlusion of the circulation to a limb (ischaemic paraesthesiae) and after its restoration (post-ischaemic paraesthesiae) is well recognized. The ischaemic paraesthesiae consist of a soft, diffuse, tingling sensation felt at the periphery of the limb and lasting only a few minutes. The post-ischaemic paraesthesiae, which have been well demarcated by Merrington and Nathan (1949), are of four types : thermal, which are hot and cold sensations felt soon after restoration of the circulation to the limb ; tingling, a soft, diffuse, vibrating feeling ; pricking, composed of numerous, irregular, fine, discrete pricks ; and pseudo-cramp, in which a sensation of movement in and tension of the muscle is experienced.

The site of origin of these phenomena has been the subject of differing opinions. Weddell and Sinclair (1947) thought that, though the ischaemic paraesthesiae arose from the nerve trunk, the postischaemic paraesthesiae had their origin in the sensory end-organs. Lewis, Pickering, and Rothschild (1931), Bazett and McGlone (1932), and Zotterman (1933), on the other hand, have all considered that the post-ischaemic paraesthesiae arise in the nerve trunk. The careful studies of Merrington and Nathan (1949) have indicated that this latter view is correct.

The primary purpose of the present work was to study the development of ischaemic and postischaemic paraesthesiae in the legs of patients suffering from sciatic pain due to a prolapsed intervertebral disc. Previous studies of ischaemic and post-ischaemic paraesthesiae have been concerned with the upper limb. It was, therefore, necessary first to study the development of these phenomena in the lower limbs of normal subjects to establish norms.

\section{Material and Methods}

The studies on subjects with sciatica were made on 21 patients with unilateral sciatic pain believed to be due to prolapse of an intervertebral disc.
Six of these patients came to operation and a prolapsed disc was found. The studies on normal subjects were made on a series of volunteers, some accustomed to clinical experiments, others entirely unused to such procedures. All the observations were made in the following way. The subject lay supine and a sphygmomanometer cuff $13 \mathrm{~cm}$. wide was placed around the thigh with its lower margin $7.5 \mathrm{~cm}$. above the upper border of the patella. The limb was elevated to empty the veins and then the pressure in the cuff was rapidly raised to $200 \mathrm{~mm}$. of mercury. The limb was then lowered to the horizontal and the occlusion maintained for 20 minutes. The time of onset of the ischaemic paraesthesiae was measured from the moment of occluding the circulation. The time of onset of the various post-ischaemic paraesthesiae was measured from the moment of the release of the occlusion. All tests were done at room temperature, and no limb was retested within 24 hours of a previous test. When both legs of a subject were tested they were done separately so as to facilitate unbiased observation of each limb.

The classification of the paraesthesiae used here is that of Merrington and Nathan described above. Attention was concentrated on the ischaemic paraesthesiae and on the thermal, tingling, and pricking types of post-ischaemic paraesthesiae. With a period of occlusion of 20 minutes pseudo-cramp occurs inconstantly and so was not studied. Because of the subjective difficulty of recognizing the disappearance of the paraesthesiae or of assessing their severity, interest was mainly devoted to the time of onset of the phenomena and not to their duration or intensity.

\section{Results}

Occlusion of the circulation to the lower limb for 20 minutes and its subsequent restoration produced exactly the same kinds of ischaemic and postischaemic paraesthesiae as have been described by Merrington and Nathan for the upper limb. This similarity covered the nature of the sensations, their 
time and order of onset, duration, and their modifiability by deformation of the skin and by pressure. The first point of interest was, however, that all forms of paraesthesiae were not felt on every occasion by all subjects. The frequency with which each type was experienced in a series of 97 tests is shown in Table I. Such omissions do not appear to

TABLE I

INCIDENCE OF THE VARIOUS PARAESTHESIAE IN 97 TESTS

\begin{tabular}{llllll}
\hline Ischaemic &. & $\ldots$ & $\ldots$ & $\ldots$ & 79 \\
Thermal & $\ldots$ & $\ldots$ & $\ldots$ & $\ldots$ & 88 \\
Tingling & $\ldots$ & $\ldots$ & $\ldots$ & $\ldots$ & 93 \\
Pricking &. & $\ldots$ &.. &. & 78 \\
\hline
\end{tabular}

have been found in the arm except by modification of the experimental conditions. Some of the omissions might be explained by a failure of observation on the part of the subject, but this cannot be the whole explanation, for in several instances paraesthesiae of one type not felt on one occasion were experienced on another. Thus seven subjects who observed tingling but not pricking at one test experienced both paraesthesiae at another, and this not always a subsequent occasion. One subject especially felt only thermal paraesthesiae in both legs. It seems, therefore, that the occurrence of all types of paraesthesiae in every subject on all occasions is not invariable. Variations occur from time to time even in the same subject under identical experimental conditions.

To assess the constancy of the time of onset of the various paraesthesiae in a large series of tests in normal subjects the means, ranges, and standard deviations were calculated and are given in Table II. It demonstrates clearly that the time of onset of each

TABLE II

TIME OF ONSET OF PARAESTHESIAE AFTER OCCLUSION AND AFTER RESTORATION OF CIRCULATION

\begin{tabular}{|c|c|c|c|c|c|}
\hline $\begin{array}{c}\text { Type of } \\
\text { Paraesthesia }\end{array}$ & & $\begin{array}{l}\text { No. of } \\
\text { Tests }\end{array}$ & $\begin{array}{l}\text { Mean } \\
\text { (secs.) }\end{array}$ & $\begin{array}{l}\text { Range } \\
\text { (secs.) }\end{array}$ & $\begin{array}{l}\text { Standard } \\
\text { Deviation }\end{array}$ \\
\hline $\begin{array}{l}\text { Ischaemic .. } \\
\text { Thermal } \ldots \\
\text { Tingling } \quad . \\
\text { Pricking } \quad .\end{array}$ & $\begin{array}{l}\cdots \\
\cdots \\
\cdots\end{array}$ & $\begin{array}{l}58 \\
65 \\
69 \\
75\end{array}$ & $\begin{array}{l}389 \\
12 \cdot 6 \\
46 \\
64\end{array}$ & $\begin{array}{c}60-1140 \\
3-45 \\
10-120 \\
40-270\end{array}$ & $\begin{array}{r}309 \\
6 \cdot 3 \\
6 \cdot 4 \\
48 \cdot 6\end{array}$ \\
\hline
\end{tabular}

form of paraesthesia does not follow a normal distribution curve but shows a wide variation and is not so constant as might be expected from the reports of studies on the upper limb. Repeated tests on the same leg in a series of normal subjects (Table III) did not show any greater constancy in the time of onset of the various paraesthesiae. Despite this wide variation, however, the order of onset of the post-ischaemic paraesthesiae was invariably thermal, tingling, and pricking, and there was not a single
TABLE III

TIME OF ONSET OF PARAESTHESIAE AFTER OCCLUSION OR RESTORATION OF CIRCULATION IN REPEATED TESTS ON A SERIES OF NORMAL SUBJECTS

\begin{tabular}{|c|c|c|c|c|c|c|c|}
\hline \multicolumn{4}{|c|}{$\begin{array}{c}\text { Time of Onset in First } \\
\text { Test (secs.) }\end{array}$} & \multicolumn{4}{|c|}{$\begin{array}{c}\text { Time of Onset in Second } \\
\text { Test (secs.) }\end{array}$} \\
\hline $\begin{array}{l}\text { Ischae- } \\
\text { mic }\end{array}$ & $\begin{array}{l}\text { Ther- } \\
\text { mal }\end{array}$ & $\begin{array}{l}\text { Ting- } \\
\text { ling }\end{array}$ & $\begin{array}{l}\text { Prick- } \\
\text { ing }\end{array}$ & $\begin{array}{c}\text { Ischae- } \\
\text { mic }\end{array}$ & $\begin{array}{l}\text { Ther- } \\
\text { mal }\end{array}$ & $\begin{array}{l}\text { Ting- } \\
\text { ling }\end{array}$ & $\begin{array}{l}\text { Prick- } \\
\text { ing }\end{array}$ \\
\hline $\begin{array}{l}225 \\
810 \\
540 \\
225 \\
150 \\
=\end{array}$ & $\begin{array}{r}10 \\
7 \\
15 \\
25 \\
45 \\
43\end{array}$ & $\begin{array}{l}20 \\
40 \\
30 \\
35 \\
54 \\
65 \\
65\end{array}$ & $\begin{array}{r}44 \\
120 \\
35 \\
70 \\
\end{array}$ & $\begin{array}{r}195 \\
390 \\
622 \\
581 \\
200 \\
60 \\
-\end{array}$ & $\begin{array}{r}5 \\
10 \\
16 \\
18 \\
28 \\
14\end{array}$ & $\begin{array}{r}23 \\
33 \\
120 \\
40 \\
62 \\
30\end{array}$ & $\begin{array}{r}\overline{135} \\
45 \\
\overline{66} \\
100 \\
100\end{array}$ \\
\hline
\end{tabular}

exception to this rule. It would seem, therefore, that despite the marked fluctuations in the times of onset of the paraesthesiae there is something fundamental in their order of onset. It was suggested that the variation on repeated testing might be less in a subject accustomed to making experimental observations than in a series of less experienced persons. Table IV shows the results of repeated tests in such a subject. Comparing the results in

TABLE IV

TIME OF ONSET OF PARAESTHESIAE IN A SERIES OF TESTS IN AN EXPERIENCED SUBJECT

\begin{tabular}{|c|c|c|c|c|c|c|c|}
\hline \multicolumn{4}{|c|}{$\begin{array}{c}\text { Time of Onset in Right Leg } \\
\text { (secs.) }\end{array}$} & \multicolumn{4}{|c|}{$\begin{array}{l}\text { Time of Onset in Left Leg } \\
\text { (secs.) }\end{array}$} \\
\hline $\begin{array}{l}\text { Ischae- } \\
\text { mic }\end{array}$ & $\begin{array}{l}\text { Ther- } \\
\text { mal }\end{array}$ & $\begin{array}{l}\text { Ting- } \\
\text { ling }\end{array}$ & $\begin{array}{l}\text { Prick- } \\
\text { ing }\end{array}$ & $\begin{array}{c}\text { Ischae- } \\
\text { mic }\end{array}$ & $\begin{array}{c}\text { Ther- } \\
\text { mal }\end{array}$ & $\begin{array}{l}\text { Ting- } \\
\text { ling }\end{array}$ & $\begin{array}{l}\text { Prick- } \\
\text { ing }\end{array}$ \\
\hline $\begin{array}{r}180 \\
735 \\
100 \\
120 \\
150 \\
180 \\
120 \\
115 \\
75\end{array}$ & $\begin{array}{r}\overline{15} \\
3 \\
3 \\
5 \\
7 \\
4 \\
7 \\
5\end{array}$ & $\begin{array}{l}65 \\
27 \\
47 \\
43 \\
50 \\
50 \\
58 \\
55 \\
47\end{array}$ & $\begin{array}{r}80 \\
45 \\
90 \\
85 \\
80 \\
83 \\
87 \\
100 \\
90\end{array}$ & $\begin{array}{l}150 \\
5 \overline{40} \\
120 \\
100 \\
\frac{105}{110}\end{array}$ & $\begin{array}{r}5 \\
3 \\
7 \\
4 \\
8 \\
9 \\
10 \\
6 \\
9\end{array}$ & $\begin{array}{l}45 \\
50 \\
47 \\
43 \\
20 \\
52 \\
44 \\
55 \\
45\end{array}$ & $\begin{array}{r}75 \\
70 \\
85 \\
90 \\
45 \\
90 \\
80 \\
85 \\
110\end{array}$ \\
\hline
\end{tabular}

Table IV with those in Table III by means of the " $F$ " test, it is found that $F$ is 1.718 for the ischaemic paraesthesiae which is not significant; $F$ is $47 \cdot 445$ for the thermal paraesthesiae which is significant at the $1 \%$ level ; $F$ is 1.159 for tingling which is not significant; ' and $F$ is 27.593 for pricking which again is not significant, though in view of the small number of observations, too much stress should not be laid on this. The trained observer, therefore, did not appear to achieve in general a greater degree of test re-test consistency than the ordinary subject.

With these facts in mind a study was made of ischaemic and post-ischaemic paraesthesiae in patients who, at the time of testing, were suffering from sciatic pain due to a prolapsed intervertebral disc. A series of 21 patients with unilateral sciatic pain was tested. The history and examination of each patient was such as to indicate that the sciatica 
was due to prolapse of an intervertebral disc. Six of the patients had a laminectomy at which a prolapsed disc was in fact found. The results of the tests are given in Table $V$. In each case the affected leg was compared with the non-affected leg as control. A statistical analysis of the results by means of Fisher's $t$ test (Table V) showed a significant difference between affected and non-affected legs with regard to the time of onset of the ischaemic

TABLE $V$

TIME OF ONSET OF PARAESTHESIAE IN A SERIES OF PATIENTS WITH SCIATICA

\begin{tabular}{|c|c|c|c|c|c|c|c|c|}
\hline \multirow{2}{*}{ No. } & \multicolumn{4}{|c|}{$\begin{array}{c}\text { Time of Onset in Affected } \\
\text { Leg (secs.) }\end{array}$} & \multicolumn{4}{|c|}{$\begin{array}{l}\text { Time of Onset in Unaffected } \\
\text { Leg (secs.) }\end{array}$} \\
\hline & $\begin{array}{c}\text { Ischae- } \\
\text { mic }\end{array}$ & $\begin{array}{c}\text { Ther- } \\
\text { mal }\end{array}$ & $\begin{array}{l}\text { Ting- } \\
\text { ling }\end{array}$ & $\begin{array}{l}\text { Prick- } \\
\text { ing }\end{array}$ & $\begin{array}{l}\text { Ischae- } \\
\text { mic }\end{array}$ & $\begin{array}{l}\text { Ther- } \\
\text { mal }\end{array}$ & $\begin{array}{l}\text { Ting- } \\
\text { ling }\end{array}$ & $\begin{array}{l}\text { Prick- } \\
\text { ing }\end{array}$ \\
\hline $\begin{array}{r}1 \\
2 \\
3 \\
4 \\
5 \\
6 \\
7 \\
8 \\
9 \\
10 \\
11 \\
12 \\
13 \\
14 \\
15 \\
16 \\
17 \\
18 \\
19 \\
20 \\
21\end{array}$ & $\begin{array}{r}65 \\
300 \\
180 \\
45 \\
175 \\
125 \\
140 \\
840 \\
480 \\
35 \\
180 \\
180 \\
195 \\
165 \\
105 \\
80 \\
900 \\
300 \\
540 \\
180\end{array}$ & $\begin{array}{r}10 \\
5 \\
10 \\
15 \\
10 \\
10 \\
12 \\
8 \\
10 \\
15 \\
10 \\
9 \\
5 \\
5 \\
5 \\
9 \\
11 \\
22 \\
8 \\
10\end{array}$ & $\begin{array}{l}12 \\
70 \\
55 \\
25 \\
50 \\
40 \\
60 \\
20 \\
70 \\
30 \\
45 \\
10 \\
45 \\
60 \\
10 \\
30 \\
22 \\
85 \\
39 \\
95 \\
30\end{array}$ & $\begin{array}{r}60 \\
70 \\
70 \\
80 \\
55 \\
90 \\
60 \\
40 \\
90 \\
70 \\
103 \\
60 \\
195 \\
49 \\
110 \\
50 \\
160 \\
62\end{array}$ & $\begin{array}{r}240 \\
720 \\
60 \\
600 \\
205 \\
1140 \\
180 \\
720 \\
230 \\
110 \\
225 \\
1020 \\
1020 \\
720 \\
105 \\
27 \\
225 \\
810 \\
540 \\
225\end{array}$ & $\begin{array}{r}77 \\
6 \\
10 \\
9 \\
5 \\
15 \\
20 \\
5 \\
15 \\
9 \\
14 \\
14 \\
40 \\
15 \\
20 \\
10 \\
7 \\
9 \\
15\end{array}$ & $\begin{array}{r}40 \\
40 \\
30 \\
10 \\
45 \\
20 \\
65 \\
30 \\
55 \\
30 \\
65 \\
40 \\
59 \\
75 \\
40 \\
75 \\
20 \\
40 \\
30 \\
110 \\
35\end{array}$ & $\begin{array}{r}90 \\
80 \\
55 \\
60 \\
40 \\
70 \\
210 \\
\overline{60} \\
270 \\
65 \\
95 \\
80 \\
160 \\
44 \\
120 \\
- \\
65\end{array}$ \\
\hline
\end{tabular}

" $t$ " $=2.390$ for ischaemic (significant at the $2.5 \%$ level), 1.679 for thermal, 0.493 for tingling, and 1.268 for pricking, all of which are not significant.

paraesthesiae, the onset being accelerated on the affected side. No difference was found with regard to the post-ischaemic paraesthesiae. As a further control a series of 12 normal subjects was tested (Table VI) and again compared by the $t$ test but no significant difference was found in either the ischaemic or post-ischaemic paraesthesiae in the two legs.

Examination of the figures for the times of onset of the ischaemic paraesthesiae in the subjects with sciatica (Table V) shows that they can be divided into two groups. In eight cases the length of time before ischaemic paraesthesiae developed in the affected leg was less than half the value for the non-affected leg, whereas in the other 10 cases the time was approximately equal on the two sides. It seems, therefore, that the significant difference between the values on the affected and non-affected sides in the whole group is due to the large difference in these eight cases.

A study of the clinical records in these eight cases showed that in every case there was an indisputable
TABLE VI

TIME OF ONSET OF PARAESTHESIAE IN A SERIES OF NORMAL CONTROLS

\begin{tabular}{|c|c|c|c|c|c|c|c|}
\hline \multicolumn{4}{|c|}{$\begin{array}{c}\text { Time of Onset in Right Leg } \\
\text { (secs.) }\end{array}$} & \multicolumn{4}{|c|}{ Time of Onset in Left Leg } \\
\hline $\begin{array}{l}\text { Ischae- } \\
\text { mic }\end{array}$ & $\begin{array}{l}\text { Ther- } \\
\text { mal }\end{array}$ & $\begin{array}{l}\text { Ting- } \\
\text { ling }\end{array}$ & $\begin{array}{l}\text { Prick- } \\
\text { ing }\end{array}$ & $\begin{array}{l}\text { Ischae- } \\
\text { mic }\end{array}$ & $\begin{array}{l}\text { Ther- } \\
\text { mal }\end{array}$ & $\begin{array}{l}\text { Ting- } \\
\text { ling }\end{array}$ & $\begin{array}{l}\text { Prick- } \\
\text { ing }\end{array}$ \\
\hline $\begin{array}{r}660 \\
960 \\
= \\
840 \\
300 \\
910 \\
870 \\
690 \\
180 \\
180\end{array}$ & $\begin{array}{r}10 \\
14 \\
18 \\
29 \\
15 \\
5 \\
20 \\
12 \\
14 \\
5\end{array}$ & $\begin{array}{l}33 \\
30 \\
60 \\
35 \\
46 \\
85 \\
40 \\
31 \\
65 \\
23 \\
65\end{array}$ & $\begin{array}{r}50 \\
\overline{5} \\
55 \\
65 \\
110 \\
60 \\
50 \\
80 \\
\overline{85}\end{array}$ & $\begin{array}{l}420 \\
480 \\
900 \\
140 \\
150 \\
240\end{array}$ & $\begin{array}{r}5 \\
6 \\
25 \\
20 \\
20 \\
8 \\
15 \\
55 \\
11 \\
5\end{array}$ & $\begin{array}{l}10 \\
20 \\
62 \\
44 \\
53 \\
75 \\
37 \\
32 \\
45 \\
10\end{array}$ & $\begin{array}{r}55 \\
70 \\
= \\
52 \\
67 \\
135 \\
47 \\
43 \\
75 \\
\frac{75}{58}\end{array}$ \\
\hline
\end{tabular}

" $t$ " $=2.035$ for ischaemic, 0.743 for thermal, 1.695 for tingling, and $0 \cdot 167$ for pricking, none of which are significant.

neurological deficit such as loss or diminution of the ankle jerk on the affected side or sensory impairment. Of the other 10 cases, only three had definite neurological signs, the remaining seven cases having sciatic pain and the orthopaedic signs associated with a prolapsed disc. The marked acceleration in the time of onset of the ischaemic paraesthesiae in sciatica due to a prolapsed disc does, therefore, appear to be related to the degree of damage to the nerve as measured by the neurological signs.

\section{Discussion}

Though prolapse of an intervertebral disc is well established as a cause of sciatic pain, there is considerable evidence to show that its mode of action is far from simple. Falconer, McGeorge, and Begg (1948) have shown both from myelographic and operative studies that sciatic pain may disappear though the prolapse persists. They also found evidence of delay in the passage of nerve impulses through the affected nerve root. They commented: "The production of sciatica thus depends on the association of two factors, the presence of a disc prolapse and changes within the nerve root." Malcolm (1951) studied the reflex time of reflexes mediated through affected roots and also found a significant delay.

The present studies adduce evidence of there being changes not only in the root but also in the nerve well peripheral to the site of disc compression. Though one might expect delay in the time of onset of post-ischaemic paraesthesiae due to slowing of conduction through the nerve, this method is much too crude a measure to detect any evidence of such a delay. Hence restoration of the blood supply to the affected and non-affected legs reveals no significant difference in the time of onset of the postischaemic paraesthesiae. In the case of the ischaemic 
paraesthesiae also there is no delay, but in fact their time of onset is accelerated to a significant degree in the affected leg. As the portion of the nerve from which the paraesthesiae arise is well peripheral to the site of disc compression, there is thus evidence of changes in the periphery of the nerve of such a nature as to impair its ability to withstand ischaemia. These studies provide no evidence as to the nature of these changes. Such pathological observations as have been made (Denny-Brown, 1933) have only shown oedema of the nerve trunk, but there may well be other changes in the myelin sheath which impair the functioning of the nerve.

It seems clear, however, that these changes, whatever their nature, are such as to render the nerve more sensitive to one form of insult, namely, ischaemia. This raises the possibility that these changes in the periphery of the nerve may make an important contribution to the symptomatology of the prolapsed disc, especially in the intractable cases which fail to gain relief even from operation. These considerations seem worthy of further study.

\section{Summary}

The times of onset of ischaemic and post-ischaemic paraesthesiae have been studied in the lower limb.
Evidence is presented that the onset of ischaemic paraesthesiae is accelerated in a limb in which sciatic pain due to a prolapsed intervertebral disc is present.

Observations are described which suggest that in the presence of a prolapsed intervertebral disc there are important changes in the periphery of the nerve.

I wish to thank Dr. W. Ritchie Russell, Dr. C. W. M. Whitty, and Dr. P. W. Nathan for their advice on this work, and Mr. J. E. A. O'Connell for his kindness in allowing me to examine his patients and for his operative findings. I also wish to thank Brigadier W. R. D. Hamilton, O.B.E., consultant physician, the War Office, for permission to report the findings in the Service patients, and Dr. A. S. C. Ehrenberg and Dr. S. Crown for advice about the statistics.

\section{REFERENCES}

Bazett, H. C., and McGlone, B. (1932). Arch. Neurol. Psychiat., Chicago, 28, 71.

Denny-Brown, D. (1933). Proc. roy. Soc. Med., 26, 1399.

Falconer, M. A., McGeorge, M., and Begg, A. C. (1948). Journal of Neurology, Neurosurgery and Psychiatry, 11, 13.

Lewis, T., Pickering, G. W., and Rothschild, P. (1931). Heart, 16, 1. Malcolm, D. S. (1951). Journal of Neurology, Neurosurgery and Psychiatry, 14, 15.

Merrington, W. R., and Nathan, P. W. (1949). Ibid., 12, 1.

Weddell, G., and Sinclair, D. C. (1947). Ibid., 10, 26.

Zotterman, Y. (1933). Acta med. scand., 80, 185. 